\title{
True Federalism? Illustrations With The Venn Diagram
}

\author{
John Otisi Kalu, PhD \\ University of Waikato, Hamilton New Zealand
}

doi: 10.19044/esj.2016.v12n8p344 URL:http://dx.doi.org/10.19044/esj.2016.v12n8p344

\begin{abstract}
The growing call for the reinvention of true federalism in many federations reflects the ambiguity inherent in federalism and its practice across countries. This article arises from the controversy it has generated, as to whether there is anything like true federalism or not, where it can be found, and how to determine it. Beyond lending a voice to the debate, this article contributes significantly by simplifying in clear terms, why there exists such calls for true federalism, what depicts it, and what specific factors should be looked out for in order to ascertain the practice of true federalism. By employing the schematics of the Venn diagram, the article creates the templates to visually perceive the interactions between political entities in a federal relation; showing the opposing forces-unification and autonomyin each entity, which true federalism aims to accommodate, nurture, and safeguard. It concludes that true federalism is the pursuit for unification and maintenance of some levels of independence among different political communities in a given federation, without the attempt by any government to suppress each of these expressions.
\end{abstract}

Keywords: True federalism, Meaning, Definitions, Illustrations, Venn diagram

\section{Introduction}

The polemics over the definition of federalism poses grave confusion, especially to emerging federations that are still aiming to evolve a workable federal governance for their societies. While many scholars find consolation in concluding that there are varieties of federalism, which means the goal to find unifying features of federalism is illusory, others continue to call for the reinvention of 'true federalism' as the only way to solve given political problems. This article is an exploratory research conducted through qualitative means to confront two main questions: a) what depicts 'true federalism'? And b) how can it be ascertained? 
To address these questions, this paper analyses relevant literature from renowned scholars on the subject and attempts to identify the common grounds in the main definitions of federalism, especially in the Anglo-Saxon literature. The reason for this is that the American model provides, to a large extent, the standard on which most formal federal states are modelled. Employing the schematics of the Venn diagram provides the means to visually illustrate the interactions between political entities in a federal relation; making it obvious how two opposing forces-unification and autonomy - in each entity influence their engagement in a federal bargain. Consequently, the article argues that it is in the maintenance of 'equilibrium or balance' between these forces that true federalism finds its meaning. It illustrates how strengthening or undermining equilibrium, or balance, impacts on the structure of a federation, and its implications on the goal of federalism, or the quest for 'true federalism'.

The remainder of this article is divided into five sections. The first reviews the literature on the search for true federalism. The second analyses key definitions, and their criticisms, from the Anglo-American literature on federalism to stipulate commonalities between them, in order to help establish what true federalism is. In the third section, the criticality of equilibrium in relation to true federalism is discussed, and how to measure equilibrium is provided. The fourth section introduces the Venn diagram, to establish its relevance to the federalist discussion. Thereafter, several illustrations are given with Venn diagrams to differentiate the 'supposed' varieties of federalism, in order to distinguish the 'true' federalism. The last section presents the answers to the main questions of this study in conclusive terms.

\section{The search for True federalism}

There is no doubt that federalism has some ambiguities that have weakened the possibility for a clear cut definition, which makes it less satisfactory for those of whom such definition is of the essence, according to (Elazar, 1987, p. 15). In spite of this, Elazar remained optimistic that careful attention can sort them out, so that in any instance, rigorous usage of the term can be maintained (Elazar, 1987, p. 29). However, about three decades have gone by, yet the ambiguities remain, as the ongoing quest for true federalism suggests. The problem is rooted in the opposing descriptors which scholars associate federalism with, such as unity and diversity, shared and self-rule, centralization and decentralization, interdependence and independence or autonomy, and general and constituent governments.

Interpreting how to combine or accommodate the sets of the contrasting values in a specific federal institutional set-up has been so difficult that operations, and also expectations, continue to vary across 
formal federal states. Where the operation is not leading to the expected results that occasioned the federal bargain, there are clamours for a reexamination of the federal system in order to enthrone true, real, genuine, proper, or pure federalism. This is exactly true especially in Nigeria-the longest surviving federation in Africa. Several nationality groups and notable Nigerians, including those that took part in the recent 2014 Confab, are calling for 'true federalism' as the only solution to the political problems in Nigeria. Elaigwu (2002, p. 84) explains that these calls are linked to the postmilitary rule situation that has led to the emergence of a very strong central government. In fact, it is becoming near impossible for any federalism scholar, or even commentators and religious leaders, in Nigeria to conclude any given piece of research, or talk, without making a reference to true federalism. $^{73}$

The quest for true federalism is equally popular and vociferous in a number of other federal countries across all continents. In India, some constitutional provisions and practices that reinforce the pre-potency of the central government are being questioned, even among youths, as to how they represent true federalism (Bhattacharyya, 2002, p. 95; IAS Baba, 2015; Mehta, 2014). In Pakistan, the predominance of the Punjabis in the central government appears to have denied political space and economic opportunities to others who continue to demand for true federalism (Khalid, 2013, p. 200; Naqvi, 2010). The argument in Mexico is that the centre's omnipotence and interference over the affairs of the states should be replaced with true federalism (Heidler \& Heidler, 2006, p. 16; Merchant \& Rich, 2003, p. 662; Ponce de León, 1999). The call is equally loud in Russia due to the excessive centralization of economic activities and maintenance of a superpower military, which no doubt frightens some of the regions that have been jostling for secession. It is now contemplated among Russian scholars, how likely it is that Russia will attain true federalism in the current administration (Heuvel, 2000, p. 23; Petrov \& Slider, 2015, p. 81; Ross, 2000, p. 417; Salikov, 2003, p. 2; Schlesinger, 2013, p. 413).

In most of the remaining federations, occasions have arisen where scholars have needed to emphasize the term 'true federalism' as against a mere mention of federalism alone. Wingo (1986, p. 476) lamented that the Supreme Court's unwillingness to employ a particular pretext in a decision, was by far the most significant factor for the collapse of true federalism in the United States. Papillon (2008, p. 9) argues that the practice of Aboriginal governance in Canada has evolved towards a type of multilevel governance

\footnotetext{
${ }^{73}$ The following are just a proportion of available examples: Adamu (2005); Bolarinwa (2014); Ejobowah (2009); Elaigwu (2002); Elebeke (2014); Ikein, Alamieyeseigha, and Azaiki (2008); Kalu (2015); Odje (2002); Sagay (2014); Senator Olubiyi Durojaiye (2014); Suberu (2009); Wayas (1998).
} 
that does not entirely reflect true federalism. Dardanelli (2010, p. 154), in a reaction to Watts' proposition about the possibility of federalism in an oligarchic system, argues that true federalism cannot function in such a system. There has also been a study that focused on true federalism with respect to Germany. ${ }^{74}$ In Belgium, Witte, Craeybeckx, and Meynen (2009, p. 379), also tried to speculate on the road to a true federalism.

With all the references to true federalism from various angles, it becomes viable to ask what true federalism actually is. While it is deducible from the discussion, of the general expectation of proponents for increased powers of the constituent governments as central to true federalism, the specific limit to such increase in powers in relation to that of the central government remains a matter for conjecture. According to Elaigwu (2002, p. 84), by 'true federalism', the protagonists of a weak central government refer to a 'confederation' or what they claim to be the classical model of federalism delineated by K. C. Wheare. He recalls that the callers insist true federalism should express clear demarcation of powers and functions among the levels of government which should be autonomous in the exercise of those powers and functions assigned by the constitution. In a similar vein, Heidler and Heidler (2006, p. 16) equate true federalism with the conferment of significant autonomy to subnational governments, who should be unencumbered to superintend their own affairs, in order to cope with dynamic economic, social, and racial diversity of the country in question.

A couple of other views are in contrast to the above. For example, Artus (2011, p. 3) opines that within a country or a currency area such as the euro zone, 'true' federalism consists in the fact that the regions with surpluses (in terms of external trade) which are richer, transfer incomes to regions with deficits which are poorer. He went further to argue that without true federalism it is difficult to conceive of how Greece and Portugal can remain in the Euro zone. ${ }^{75}$ Similarly, Verny (1998) argues that a true federalism has both a distribution of political power specified in the constitution and a direct relationship between political power and the individual citizen. Furthermore, Moots (2009, p. 402) argues forcefully that what distinguishes true federalism from the mere use of the federal principle is that it is more than just sharing of powers coupled with self-rule for the sake of other ends, rather distribution is necessary for its own sake.

For Wegierski (2011), what constitutes true federalism is the empowerment for the expression of divergent tendencies that would otherwise have a centrifugal effect on a given polity. This resonates with Benoit Pelletier's earlier assertion that the true meaning of federalism is the

\footnotetext{
${ }^{74}$ See Artus (2011).

${ }^{75}$ Artus (2011, p. 4).
} 
necessary respect for differences and diversity, in which absence he argues amounts to rejecting the very basis of federalism Pelletier (2005, p. 3). Relatedly, Hodgins and Wright (1978, p. 51), identifies fine balance and non-interference between two levels of government as the basis of true federalism; the reason being to safeguard the differences earlier mentioned.

Meanwhile, there are many other scholars who believe there is nothing like 'true federalism'. Their conviction is that every federal system is designed to achieve some specific goals with regard to the peculiar situation of each society; therefore whatever achieves this mission becomes a 'true' federalism for that particular society. For example, Livingston (1956, p. 4) argues that federalism admits of infinite variations, and Elazar concurs to this with his assertion that there is more than one way in which federalism could be applied (Elazar, 1987, p. 6). In the opinion of Franck (1968, p. 169) the concept of federalism is malleable enough to bend with the realities. Consequently, Ejobowah (2009, p. 513) builds on the above ideas and argues that it would be more appropriate to speak of varieties of federal arrangements and regard each of the summarized prescriptive arguments as relative or context-specific. In this vein, he concludes succinctly that there is no such thing as 'ideal', 'perfect', or 'true' federalism.

Conceding to the validity of a variety of federal arrangements as suggested above does not help matters but has been the key contributing factor to the increasing call for true federalism. It will amount to a stark insensitivity to ignore the need to identify a unifying nature of federalism. There is a definite expectation that most people have in mind when they make reference to true federalism. Alternatively, it could be argued that since federalism has been alleged to exist in different shades, maybe one of the shades could possibly present the system that proponents stress as 'true' federalism. Unfortunately, even among the proponents for true federalism, there seems to be contradictions relating to what constitutes true federalism. Three distinct ideas summarize their positions as follows:

a) Weak central government against stronger constituent governments confederation;

b) Strict adherence to the division of powers between levels of government to safeguard the autonomy of constituent governments classical model of federalism; and

c) The necessity of sharing and distribution of benefits across the polity such that wealth can be redistributed from richer regions to poorer regions cooperative model of federalism.

Therefore, an effort is made below to assess the question of true federalism and to find out what depicts it by analysing the key definitions that have shaped the various positions and expectations as pointed out above. 


\section{Establishing True federalism}

It should be recalled that K.C Wheare made the first bold attempt to formulate a clear conception of federalism, following his analysis of the American constitution which established the premier modern federal system. He began with an initial observation that "most of those who use it agree on this, that they have in mind an association of states, which has been formed for certain common purposes, but in which the member states retain a large measure of their original independence" (Wheare, 1963, p. 1). Acknowledging the possibility of relating this notion of federalism to several political associations, and the ambiguity it generates, Wheare set out to uncover what is distinctive of the system established in the US Constitution. He observed that in earlier associations of states, including the US under the Articles of Confederation, the organization was such that the general government was dependent upon the regional governments or vice versa; whereas in the US Constitution, he found none was dependent on the other as each level has areas of independent jurisdictions. ${ }^{76}$ This distinction distinguishes confederation, which presents constituent units' superiority, and a unitary system, in which the general government is superior. Federalism is seen as the centre of the two extreme systems, in which case, each is independent and limited, and none dominates the other.

However, a growing overlap and mutual interdependence has been observed between the levels of government of federal systems, which makes the premise of independence, either overemphasized or simply unfeasible as critics argue. ${ }^{77}$ The critics, therefore, dismiss Wheare's definition as being unduly legalistic and utopian. Meanwhile, the alternative definitions offered have also received criticisms which demonstrate the nature of the polemics. To start with, Livingston (1956) argued that it was rather an over-emphasis to stress the institutional structure of power division as the basis of Wheare's definition: "The essential nature of federalism is to be sought for, not in the shadings of legal and constitutional terminology, but in ... the forces that can be called 'the federal quality of the society' which comprises 'diversities grouped territorially’ within a society” (Livingston, 1956, pp. 1-3).

The analyses and criticisms of Wheare and Livingston's formulations form the basis of subsequent scholarly attempts at extrapolating federalism. For this reason, I limit my review on those propositions that are distinct from those made by the above two scholars, and also, focus of which direct us to a

\footnotetext{
${ }^{76}$ An association of states, so organized that powers are divided between a general government which in certain matters-for example, the making of treaties and coining of money-is independent of the governments of the associated states, and, on the other hand, state governments which in certain matters are, in turn, independent of the general government” (Wheare, 1963, pp. 7, 2).

77 See Elazar (1969, pp. 379-410); Grodzins (1966, pp. 84-85).
} 
different aspect of federalism to consider. William Riker reinforces Wheare by stressing the division of powers between levels of government. However, he went further to add that the allure for military security and economic expansion are paramount for the formation of a federation through what he called the 'federal bargain', between prospective national leaders and officials of constituent governments (Riker, 1964, pp. 11-12). As a result, he believes that the design of the federal system would be different across various societies depending on what is important for the federal bargain. Hence, in some cases, a level of government might just have a single area of autonomous action, against another level that might have many. According to Riker, if the central government has more areas of autonomous actions, then it is a 'centralized federalism' and if the constituent governments have more, then it is 'peripheralized federalism'. 78

Carl Friedrich (1968) adds another important dimension of thought, which seems to illuminate Livingston's sociological view of federalism. At the root of his discussion of federalism is the prominence of communities or separate political entities. He began by observing that "federal order typically preserves the institutional and behavioural features of a 'foedus'-a compact or treaty between equals to act jointly on specific issues of general policy” (Friedrich, 1968, p. 6). He stresses further: "we have federalism only if a set of political communities coexist and interact as autonomous entities, united in a common order with an autonomy of its own” (Friedrich, 1968, p. 8). As such, he concludes that federalism is also, and perhaps primarily, the process of federalizing a political community; that is to say, the process by which a number of separate political communities enter into arrangements for working out solutions (Friedrich, 1968, p. 7).

Another perspective emerges in Elazar and Watts' writings. They both recognize the social factors and diversities that shape federalism, and as well, they note the importance of formal structures which regulate the forces from the diverse territorial groups. Elazar is the chief exponent of the 'covenant' basis of federalism, ${ }^{79}$ which has become very attractive as it simplifies the subject. According to him, "a covenant is a morally-informed agreement or pact between people or parties having an independent and sufficiently equal status, based upon voluntary consent, and established by mutual oaths or promises witnessed by the relevant higher authority" (Elazar, 1980, p. 6). Against this backdrop, Elazar asserts that a federal arrangement, in essence, is "one of partnership, established and regulated by a covenant, whose internal relationships reflect the special kind of sharing that must

\footnotetext{
${ }^{78}$ Riker (1964, pp. 5-7).

${ }^{79}$ This is evident in most of his works on federalism including the following: Elazar (1980, pp. 6-9; 1987, p. 5; 1991, p. 232; 1993, p. 194; 1994, pp. 111-129).
} 
prevail among partners, based on a mutual recognition of the integrity of each partner and the attempt to a special unity among them” (Elazar, 1987, p. 5). He summarized by presenting the simplest possible definition of federalism, as 'self-rule plus shared rule'. 80

Watts develops further the idea of self-rule and shared rule as central to federalism, for which he believes the former is necessary to safeguard the prior organic ties the diverse groups have had before coming to form a joint government-shared rule. Examining several federations, he however found that, what was distinctive about the social situations which produced federalism was not merely the duality of demands for union and regional autonomy, but the relative balance or equilibrium in each community between the conflicting forces for unity and diversity" (Watts, 1966, p. 93). Hence, he adds the notion of 'balance' or 'equilibrium' into the debates of federalism as its key distinguishing feature. This marks a point of theoretical saturation regarding the definition of federalism in the literature. It is therefore rare to see any subsequent definition of federalism that departs significantly from the conceptualizations explored above. The table below provides the summary of these key formulations in order to ease the task of extrapolating the central feature that signals what 'true' federalism is.

Table 1 Major definitions and extraction of key elements of federalism

\begin{tabular}{|c|c|}
\hline Main scholastic views of federalism & Key Elements or Emphases \\
\hline $\begin{array}{c}\text { Federalism as Institutional Structure-Dual Federalism } \\
\text { Most of those who use the term [federalism] agree that } \\
\text { they have in mind an association of states, which has } \\
\text { been formed for certain common purposes. The federal } \\
\text { principle is the method of dividing powers so that the } \\
\text { general and regional governments are each within a } \\
\text { sphere co-ordinate and independent of one another.- } \\
\text { Wheare (1963, pp. 1, 10) }\end{array}$ & $\begin{array}{l}\text { Division of powers; associated states; } \\
\text { forming joint government; general and } \\
\text { regional government; independence; } \\
\text { coordinate, non-subordination. }\end{array}$ \\
\hline $\begin{array}{l}\text { Federalism as the Quality of the Society } \\
\text { Federalism is a device to protect the federal quality of a } \\
\text { society, which comprises 'diversities' grouped } \\
\text { territorially. ... uniting into a single polity a number of } \\
\text { component polities so that the personality and } \\
\text { individuality of each are largely preserved, while } \\
\text { creating in the new totality a separate and distinct } \\
\text { political and constitutional unit. - Livingston (1956, } \\
\text { pp. 2, 9) }\end{array}$ & $\begin{array}{l}\text { Diversity; territorial separate groups; } \\
\text { interactions; joint government; tensions } \\
\text { between groups to undermine the other; } \\
\text { need to protect and preserve diversities. }\end{array}$ \\
\hline $\begin{array}{l}\text { Federalism as a Bargain } \\
\text { Federalism is a bargain between prospective national } \\
\text { leaders and officials of constituent governments for the } \\
\text { purpose of aggregating territory. This bargain can be } \\
\text { identified with the following rules: two levels of }\end{array}$ & $\begin{array}{l}\text { Joint establishment of a central } \\
\text { government through bargain by constituent } \\
\text { political entities; division of powers with } \\
\text { jurisdictional overlap-two governments } \\
\text { rule same land_-and independence. }\end{array}$ \\
\hline
\end{tabular}

${ }^{80}$ See particularly Elazar (1987, p. 12). 


\begin{tabular}{|c|c|}
\hline $\begin{array}{l}\text { government rule the same land and people; each level } \\
\text { has areas of action in which it is autonomous; and there } \\
\text { is some guarantee of the autonomy of each government } \\
\text { in its own sphere. - Riker (1964, p. 12) }\end{array}$ & Guaranteed autonomy of each government. \\
\hline $\begin{array}{c}\text { Federalism as a Process } \\
\text { Federalism is the process of federalizing a political } \\
\text { community...by which a number of separate political } \\
\text { communities enter into arrangements for working out } \\
\text { solutions, and making joint decisions on joint problems. } \\
\text { We have federalism only if a set of political } \\
\text { communities coexist and interact as autonomous } \\
\text { entities, united in a common order with an autonomy of } \\
\text { its own.-Friedrich (1968, pp. 7-8) }\end{array}$ & $\begin{array}{l}\text { Separate political communities; process; } \\
\text { interaction; a formed arrangement for } \\
\text { common purpose; division of powers to } \\
\text { grant autonomy to each level of } \\
\text { government; ongoing tensions that need to } \\
\text { be institutionally checked. }\end{array}$ \\
\hline $\begin{array}{l}\text { Federalism as Sharing (i.e.; self-rule plus shared rule) } \\
\text { Federal principles are concerned with the combination } \\
\text { of self-rule and shared rule. They grow out of the idea } \\
\text { that free people can freely enter into lasting, yet limited, } \\
\text { political association to achieve common ends and } \\
\text { protect certain rights while preserving their respective } \\
\text { integrities.-Elazar }(1987, \text { pp. } 5,33) \text {. }\end{array}$ & $\begin{array}{l}\text { Political partners; joint establishment; } \\
\text { independent and joint spheres; } \\
\text { relationship; mutual respect; plausibility of } \\
\text { tension; protection of differences across } \\
\text { political communities. }\end{array}$ \\
\hline $\begin{array}{l}\text { Federalism as Balance/Equilibrium of opposing } \\
\text { femands } \\
\text { Federalism is about the relative balance or equilibrium } \\
\text { in the conflicting demands for union and regional } \\
\text { autonomy within different federating communities. The } \\
\text { essence of federalism is the value of perpetuating both } \\
\text { union and diversity at the same time. } \\
\text {-Watts (1966, p. 93); (2008, p. 8). }\end{array}$ & $\begin{array}{l}\text { Separate regions; joint government; self- } \\
\text { government; identified balance in } \\
\text { opposing demands as key; preserving the } \\
\text { balance; relationships or interactions; non- } \\
\text { subordination; equality. }\end{array}$ \\
\hline
\end{tabular}

From the table, Watts' advancement of the notion of equilibrium captures the central message that can be deduced in the others, and provides the clue to pin-point what federalism precisely is; or 'true federalism' that is devoid of prefixes and other adjectival qualifications. At the foundation of each definitional conception is the idea of 'political entities' wishing to come together, in anticipation of certain benefit(s) that can only result if they unite. These entities, also have their separate values which they can only protect if they stayed independent or autonomous of the other political entity. How to design a system that would incorporate and or resolve this dilemma becomes the challenge of federalism. ${ }^{81}$ Hence, in most of the arguments, proponents have always presented different poles of possibilities for federalism such as peripherialized and centralized options, among other varieties of federalism. For example, Livingston asserts that federalism is thus, not an absolute but a relative term; for there is no identifiable point at which a society ceases to be unified and become wholly diversified (Livingston, 1956, p. 4). A similar

\footnotetext{
${ }^{81}$ This is true for all formal federal systems and quasi-federal organizations; even those that are currently being debated like the European Union.
} 
assertion is made by Elazar, and also Watts, who opines that federalism can be considered a broad genus of political organizations of which there are different species (Elazar, 1987, p. 6; Watts, 2008, pp. 8-9).

The difference in categories depends on the status, outcome, or result of the tension between two opposing demands - the desire for union against independence (Wheare, 1963, p. 37), fostering integration or unification against diversity (Livingston, 1956, p. 4), preserving shared rule against selfrule (Elazar, 1987, p. 5), and the goal of maintaining maximum and or minimum powers by each of the levels of government (Riker, 1964, p. 6). That is to say, the prominence of each of the opposing demands in the scheme of things distinguishes the federal institutional forms. For example, if the desire for independence trumps that for union, the result is a confederation; whereas the prominence of the desire for union above independence results in a unitary system. But a federation represents the system in which both demands are relatively prominent and almost, if not, in equilibrium.

The importance of balance or equilibrium is implicitly recognized by each of these scholars in their arguments. For instance, Livingston concludes that federal system is an institutionalization of the compromise between two opposing demands, and that the federal constitution structures the limits of this compromise (Livingston, 1956, p. 6). More forcefully, the constitution will be more or less federal in accordance with the relative strength of the two demands (ibid). Similarly, Wheare's emphasis on the independent jurisdiction of each level of government is premised on the need to ensure that none dominates the other, which is an allusion to the target of equilibrium and balance.

Furthermore, Riker, in distinguishing federalism between where a level of government possesses maximum powers to make unilateral decisions in all but one and vice versa, observes that few federalisms relatively lie at either extremes (Riker, 1964, p. 6). In other words, federalism mostly lies at the middle, where no level can unilaterally make a decision affecting the entire union, which accentuates balance. For Elazar's self-rule and shared rule combination, he points out that each of these factors has to be limited in such a way to provide for the energetic pursuit of common ends while maintaining the respective integrities of all parties, without replacing or diminishing prior organic ties (Elazar, 1987, pp. 6, 12).

It can therefore be argued that if equilibrium is not aimed at and balance not maintained, one of the demands under tension would overshadow the other, or suppress it, whereas it has been shown that it is necessary to maintain a balance between both. How can equilibrium be achieved if there are no instruments to safeguard each of the values? It has to be noted that federalism is neither a pragmatic nor heuristic exercise. Instead, 
federalism is principled, focused, and reflects a conscious design and commitment to safe-guarding these two opposing demands-an idea that Wheare had posited as the federal principle. There is a strong reason, therefore, to aver that true federalism is concerned with the goal and means of achieving and maintaining equilibrium between the forces that make political entities want to be united and the forces that make them want to remain separate, autonomous, or independent.

\section{The question of equilibrium}

Having established the criticality of equilibrium or balance to distinguish federalism, the challenge is on how to determine it, or where to focus attention in order to assess equilibrium. Wheare, and the proponents of institutional approach to the study of federalism, emphasizes the division of powers between two levels of government as the foundation of federalism. If one links the pursuit of equilibrium or balance to this task, he or she confronts the challenge of determining the weight of powers assigned to each level of government in order to ascertain whether there is equilibrium or not. Most scholars have viewed areas of function that fall under the independent jurisdiction of a level of government as an indication of what powers the particular government wields. Functions such as defence, currency, and commerce are examples of areas of function mostly placed under the central government's independent jurisdiction, while social services, agriculture, and education are examples of those placed under the subnational government's independent jurisdiction.

Focussing on functions does not help to find equilibrium. Riker's observation is instructive: "there is hardly any mechanical means of totting up numbers and the importance of areas of action in which either government is independent of the other" (Riker, 1964, p. 7). Similarly, the term 'power' (as in the division of powers of government) is too abstract, and obfuscates the possibility of finding balance. No wonder Riker argues that it is better to look beyond the division of boundaries and instead to survey the whole range of action in a systematic way, using 'scholarly common sense' (Riker, 1964, p. 52). This suggestion is interesting but does not really offer a specific guide to direct scholars towards determining equilibrium. Unfortunately this is the missing link that has made federalism remain ambiguous, and the search for true federalism an elusive goal.

In order to ease this difficulty, I argue that focus should not be entirely on areas of function or powers of government but instead on the interactions of the forces that shape the design of that particular structure of government- the centrifugal and centripetal forces. This is so because power is a means to an end; the end of federalism is the safeguard of these opposing demands. It must be remembered at all times that the demands mentioned 
relate to the needs of political entities which come together because they value expansion as well as preservation. Hence, the equilibrium talked of should be looked for in the empowerment of each level of government to freely express the mandate that reinforces their establishment or being, i.e., the pursuit for unification and the goal of maintaining some levels of independence, without the attempt by any level of government to suppress each of these expressions.

The empowerment for these forces can be ascertained in the language of the constitution, for which every federal constitution reserves certain spheres of activities for the independent action of a particular level of government; this is a primary prerequisite. ${ }^{82}$ However, because of the possibility that some operators of the constitution may dump or misapply constitutional provisions, the practice of the constitution must equally be seen to tolerate and enhance the expression of the opposing demands as prescribed in the law of the constitution, to represent true federalism. Because these forces are in tension, there is a possibility of each tending to overshadow the other and also the possibility of the other resisting the pull. Therefore, terms like 'agitation' and 'resistance', both of which lead to compromise, are key indicators to signal the status of equilibrium. The pulls and restraints of these forces in the federal intercourse to maintain balance, finds perfect illustration with the Venn diagram as demonstrated in the next section.

\section{Employing the schematics of the Venn diagram}

The Venn diagram involves the use of overlapping circles to represent propositions and ideas in a logical way to simplify and enhance understanding. Each basic Venn diagram is made up of at least two overlapping circles to represent groups (called sets) that relate to each other which are being studied. The idea of the diagram is, first, that different contents in each set or group can be sorted or separated, and represented by regions, numbers, or areas in each circle. Secondly, the circles are made to overlap in order to merge similar contents from different circles under common intersecting region(s), formed by the coming together of the two groups of circles, while leaving their separate contents in distinct regions outside this intersection. The goal is to provide a visual illustration of all possible logical relations between the groups indicated in the same diagram.

In relation to federalism and the problem of our study-determining equilibrium — sets are political entities. To make it less complex in order to

\footnotetext{
${ }^{82}$ This suggests that whoever is looking for federalism or true federalism should begin by observing the constitution of the state or union in question, before other steps could be added to confirm the practice of true federalism there.
} 
be easily understood, two political entities, which is the minimum requirement for a federal bargain to take place, will be used all through the illustrations here. ${ }^{83}$ Political entity $\mathrm{A}$ is represented primarily by a yellow circle and political entity $\mathrm{B}$ is represented by a blue one. Each entity has got the two opposing demands contained in them; one, pulling it back to preserve her values (independence), and the other pushing it to extend by joining another entity to enhance perceived economic gains or strengthened security. The former refers to centrifugal forces and it leads to the retention of a regional government, while the latter refers to the centripetal force and leads to the establishment of a central government for the two entities.

Therefore, I start by presenting two circles to represent two political entities $A$ and $B$ (see figure 1). In each circle, I separate the two opposing demands into different marked equal areas on the circle to show the equilibrium of both as seen in Figure 2. In addition, I have indicated the areas of similar contents - centripetal demands ${ }^{84}$ - in the two circles that would be merged in setting up the federal government. Finally, I merged the two circles and the political entities become regions to illustrate the formation of a federal state.

Figure 1. Two Political Entities - A and B
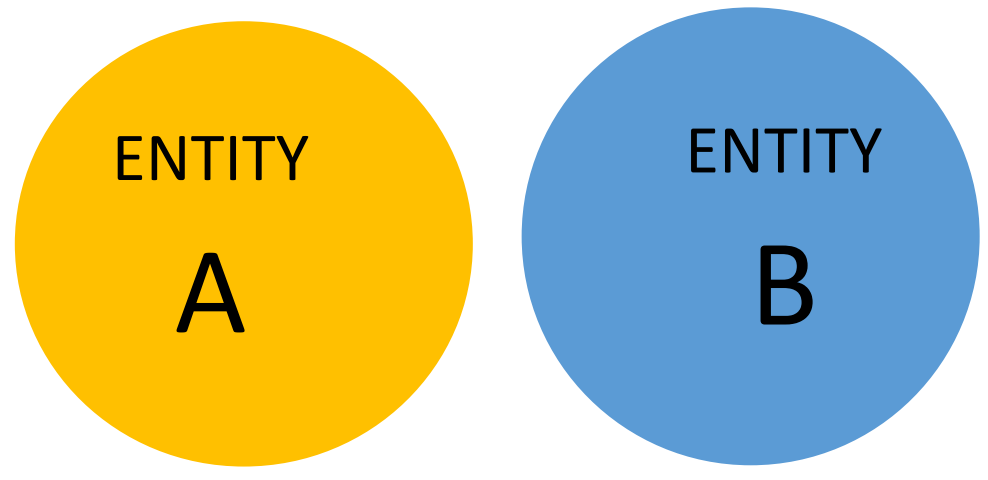

\footnotetext{
${ }^{83}$ While it is true that most federations have much more than two federating units, the main point here is to show that in all of them, two opposing demands - unification and independence - influence their establishment and subsequent decisions in the union. Hence, the mental picture from the illustrations with two units can be extended and reapplied in all federations regardless of the number of federating units. The key message is to understand that the centre is formed by merging the centripetal forces of each federating unit and leaving out their centrifugal demands to be furthered by their independent sub-national governments.

${ }^{84}$ These centripetal forces vary by context depending on the contributing factors that led to the particular federal bargain - military and security threat, and economic expansion among others.
} 


\section{Political Entity A}

Figure 2. Opposing demands in each Political Entity

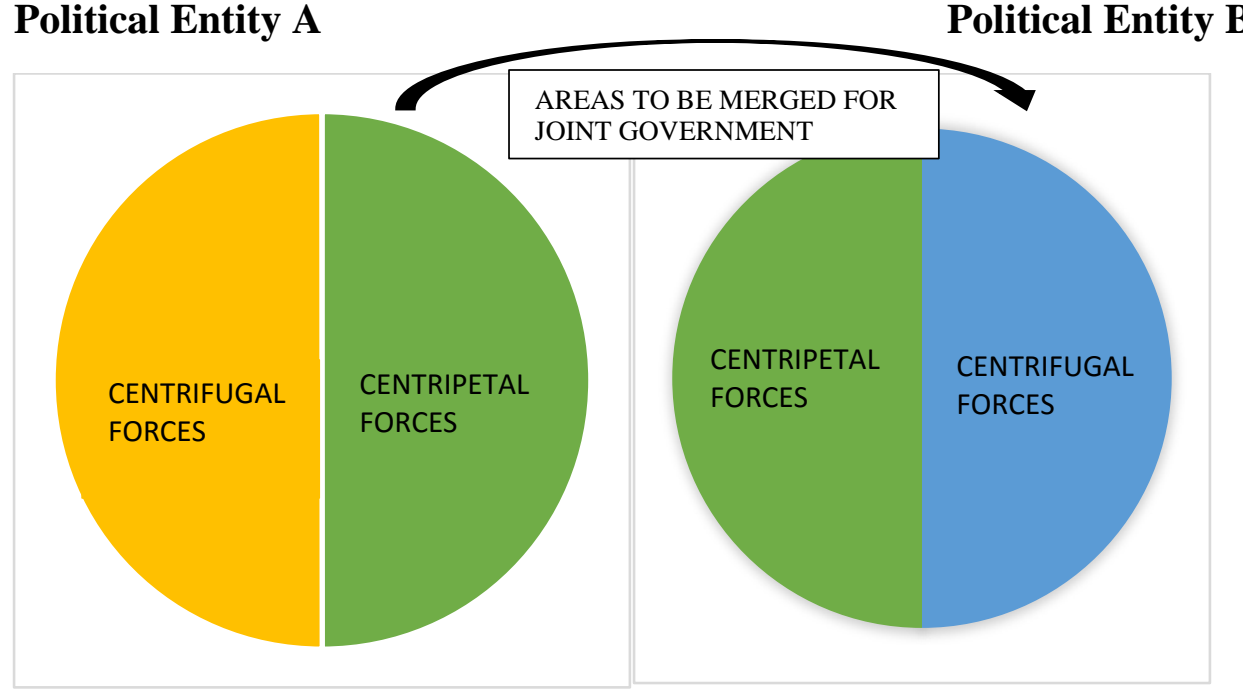

Note that the choice of green colour to represent the centripetal forces in each entity is borne by the fact that the combination of the two primary colours - yellow and blue - that represent the political entities, results in green. As is known, the central government sphere is made up of the combination of elements from the two federating units. This finds illustration in Figure 3 below.

Figure 3. Formation of a Federal State - 'True' Federalism diagram

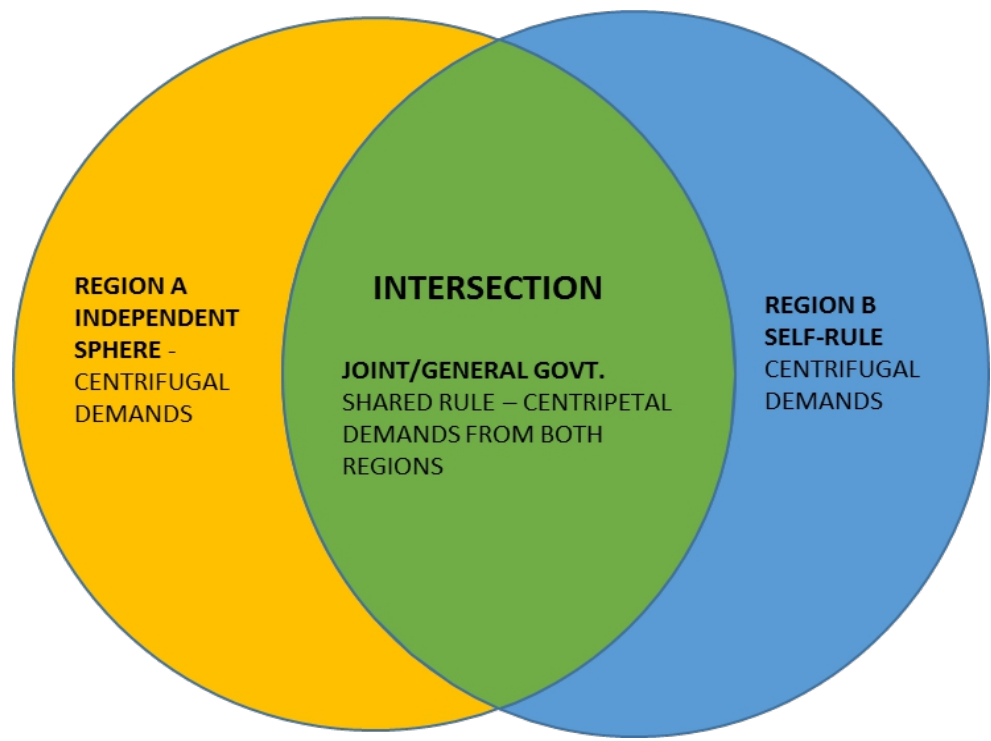

The three diagrams above illustrate how the presence of two opposing forces within each of two separate political entities leads to the 
formation of a federal state, to design a constitution that permits the accommodation and expression of opposing demands. It is clear that the root of federalism is about two entities which come together to create an additional central government by sacrificing an equal 'part', but not all, of their original independence to the emerging joint government. Figure 3 illustrates this perfectly, as the central or general government is shown to be formed by the coming together of the two circles representing the political entities, without drawing another circle for the new government to make it three. This shows that the general government is not a primary government entity, but a secondary government that is made up of combined inputs from the federating entities in terms of function and personnel.

It means that whatever functions, roles and powers are allocated to the central government are products of contention, negotiation, and compromise between the primary governments - federating units. This means that, while the constituent governments face pressures from the opposing demands in question, the central government is supposed to have one singular mission of unification, without any centrifugal inclination, since it is not a basal government. In pursuit of the goal of unification for which it was established, the central government often tries to expand its scope, by introducing new policies or ignoring the original design of the federal constitution, which means the central government gradually encroaches into the remaining independent spheres of the federating entities. ${ }^{85}$ This possibility is illustrated in Figure 4 and it deviates from 'true' federalism; with the attempt to erode, instead of safeguarding, the reserved independence of the constituent governments. ${ }^{86}$

\footnotetext{
${ }^{85}$ The Nigerian federation from immediately after the first republic (1963-1966) to date offers a clear representation of this situation which most scholars term 'centralized federalism'. There is hardly any significant sphere of function that the constituent governments are allowed to differ in order to institutionally secure diversity. Instead, every effort is made to unify activities, policies, and even operations, despite the stark differences that exist among the people that make up Nigeria which led to the choice of a federal system at the onset.

${ }^{86}$ It is not to say that this is bad; if both entities equally give-up their remaining independence, integration or unification would have taken place, and federalism may give way to Unitarianism. But if one entity still wishes to maintain its independence, then it will amount to forced unification.
} 
Figure 4. Prominence of centripetal forces - Towards Unification

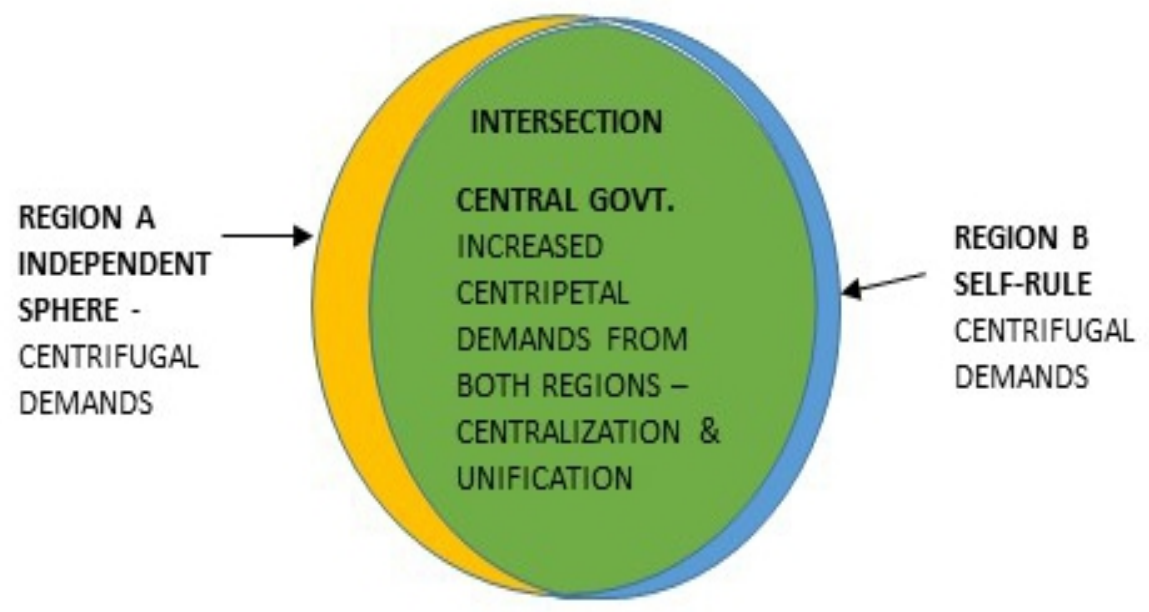

However, the pull of centrifugal forces might be so strong that the federating entities would be making several agitations to increase their independent spheres, which automatically means encroaching into the reserved area for centripetal demands. Even though this is not often the case compared to the instance mentioned above, when it does happen, the central government might be eroded or undermined; neither of which represents ‘true' federalism as I argue. This possibility is represented in Figure 5.

Figure 5. Prominence of centrifugal forces - Towards disintegration

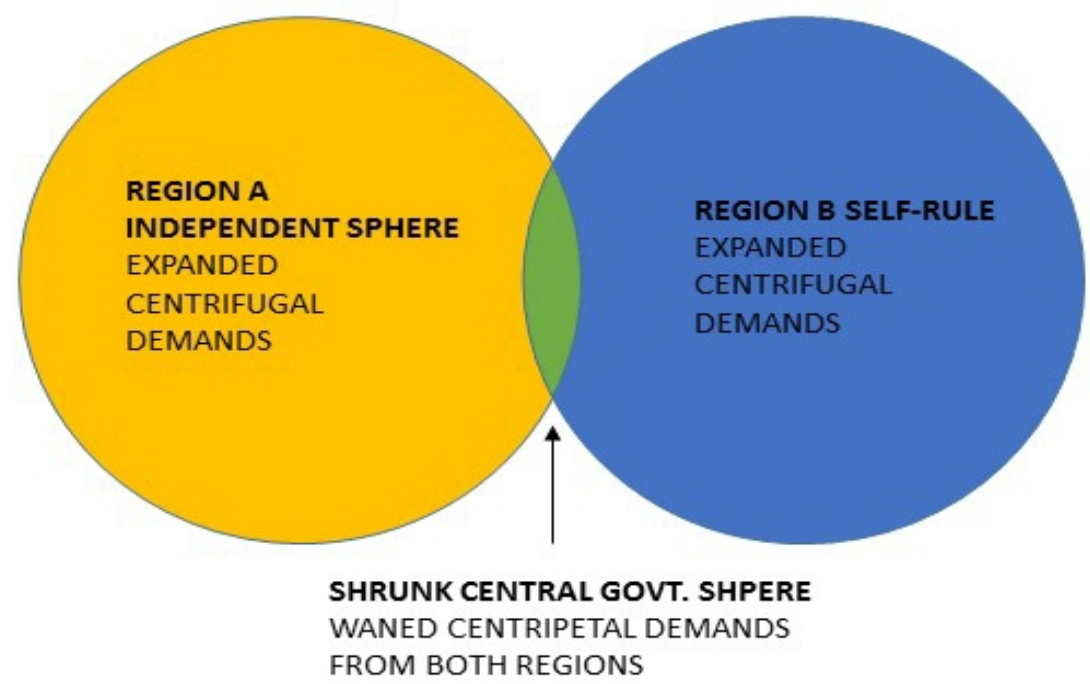

Meanwhile, in both instances represented in Figures 4 and 5, there are usually pressures from the other government(s) within the federation to push back whatever demand that is encroaching into the spheres of the other valued demand. For instance, in case the central government came up with 
new policies that the constituent units felt encroached into their independence, the centrifugal forces would rise to resist further implementation of the centripetal force's induced policies. This reshapes the expanded central government sphere on the federalism diagram to the original shape (Figure 3) that reinforces the equilibrium of the two demands.

That is to say, encroachments are very possible in a federal relationship to underline the fact that two opposing forces are in tension, and competing at all times to trump each other, yet are each expected to be defended, accommodated, and safeguarded. True federalism is poised to actualize this goal by permitting agitations, negotiations, and compromises, between empowered distinct political entities within a state. ${ }^{87}$ It is through the expression of these three key features that equilibrium or balance can be perceived, as well as the ascertainment of the practice of true federalism in a country. Where agitations are ignored, negotiations are not welcome, and the expression of one of the opposing demands is suppressed, instead of attempts to reach a compromise that will restore balance, it is an indication of a rape on true federalism.

Unfortunately, the expansion of the central government often signals the hegemony of one of the federating units above the other(s), which might have gradually taken over the central government using several ploys. The dominant group in the central government pursues this expansion under the pretence of unification as a centripetal pull, and attempts to eliminate every trace of centrifugal allegiance. But in reality, they uphold their own centrifugal values and make these become the national values, ${ }^{88}$ which often instigates other suppressed constituent unit(s) to agitate for selfdetermination instead. This is because they are forced to sacrifice their remaining independence for unification, or even being subsumed, against their original intention for the federal bargain. This situation is illustrated in Figure 6 below.

\footnotetext{
${ }^{87}$ Outside federal systems, regions might be empowered to act on some areas, but that comes at the mercy of the superior central government. In federal systems, federalism means that both levels of government are superior on their own terms and none can boss the other without the possibility of being challenged.

${ }^{88}$ To a large extent, India and Pakistan provide a suitable illustration for this with the choice of Hindi as the national language in the former as many people argue, and also the strong Punjabi influence in the latter. Also, subsequent Nigerian leaders from the North have attempted to suppress other centrifugal inclinations within the federation while promoting theirs as the National values - the move to Islamize Nigeria is illustrative.
} 
Figure 6. Expanded centre cum suppression of one political entity

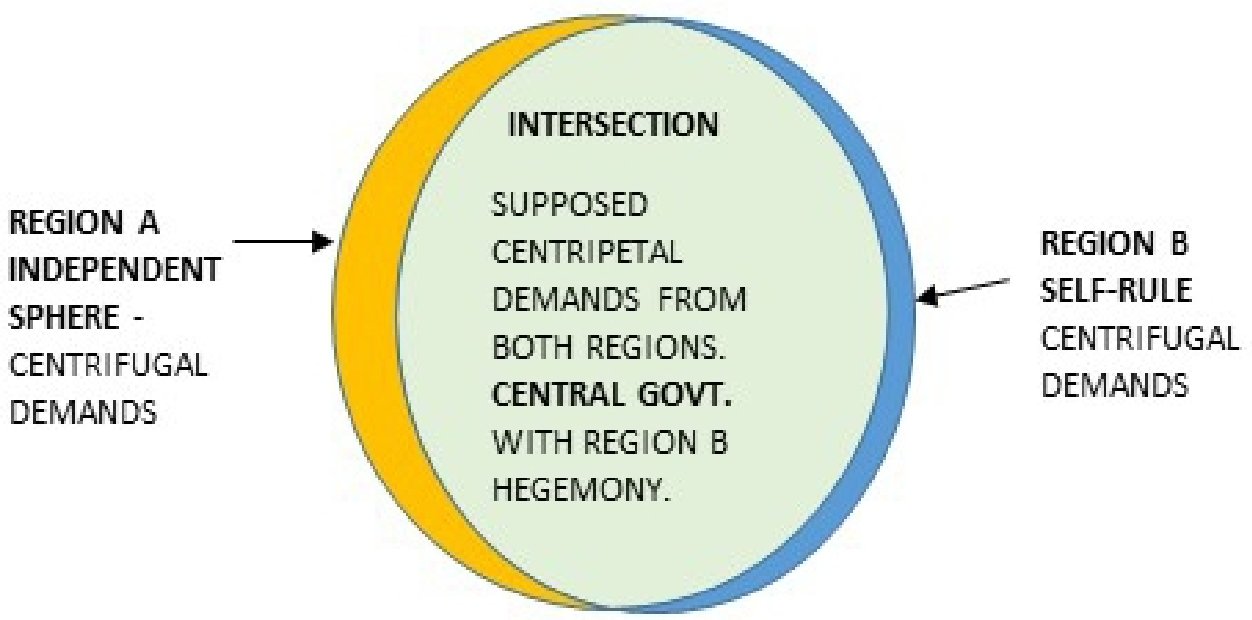

From the diagram, a few things can be observed. First, it clearly shows an enlarged central government sphere. Secondly, the neutral green colour the centre had in Figures 3 and 4, to show the equal influences from both constituent units represented by yellow and blue, has changed to a lighter blue. This indicates a larger insertion of blue elements into the centre in relation to its partnering yellow entity. Therefore, while the diagram depicts eroded independent jurisdictions of the two federating units, one of them - entity or region B-has actually gained more through the central government sphere while the other has genuinely lost its independent jurisdiction. This is far from a true federalism; shared and independent jurisdictions should always be maintained and reinforced, instead of treating one aspect with contempt.

\section{Conclusion}

This article has confronted the question of true federalism which has been largely clamoured for across different countries. The boundary between federalism and true federalism remains blurred as both are presumably committed to the same goal, but the article explains why it has become attractive for proponents to stress 'true' federalism instead. This is rooted in the idea that there are a number of ways federalism can manifest within a broad genus of federal political systems, which could make federalism irrelevant if it is possible across all political systems; hence, the continuous call for true federalism. Employing the schematics of the Venn diagram has helped to create a visual and mental picture of what depicts federalism or true federalism.

With regard to the question of true federalism, of the three ideas given by proponents, this article concludes, firstly, that true federalism does 
not mean a weak central government against stronger constituent governments, which represents a confederation. Both the central and constituent governments are strong but limited in true federalism, as shown in Figure 3. Secondly, adherence to the division of powers between levels of government to safeguard the autonomy of constituent governments, as emphasized in the classical model of federalism, is important for the practice of true federalism, but not to be followed strictly. This is to enable the possibility for sharing and distribution of benefits across the polity, such that wealth can be redistributed from richer regions to poorer regions. Even though this particular goal continues to be the source of conflicts in federal relations, it remains a vital feature of true federalism; this means the tension it generates is part of the feature of true federalism.

In response to the second question - how true federalism can be ascertained - this article concludes that each of the three features of true federalism identified above has to be surveyed in a systematic way to determine their reinforcements in a given federal system. This means analysing the law of the constitution and its practice, as well as observing the wrangles within the federation. More concretely, this article finds that there is tension in each of the features of true federalism which is manifested in constitutional provisions and practices to represent centripetal and centrifugal demands, and concludes that equilibrium or balance is the key. This should be looked for in the empowerment of each level of government to freely express the mandate that reinforces their establishment or being. That is, there should be a pursuit for unification and the goal of maintaining some levels of independence, without the attempt by any level of government to suppress each of these expressions.

Conclusively, there is an inevitable tension in every 'true' federalism that makes agitations, resistances, and compromises the key indicators towards balancing the pulls and restraints in the federal intercourse, without which the practice cannot represent true federalism. Therefore, if: a) there is a constitutional division of powers between levels of governments, such that constituent governments represent diverse political communities along territorial lines, b) in practice each government's autonomous sphere cannot be encroached, regardless of the need to permit for sharing and distribution, without prior consent of that government, and c) agitations from each government, or territorial community, is not ignored or brutally supressed but considered and negotiated, then true federalism is evident in the society in question. These conditions can be found present in most federal systems across the globe, and even the European Union to a large extent, regardless of the model or variety of federalism in practice. In the majority of places where the call for reinventing true federalism is most loud, like Nigeria, 
India, Pakistan, and Russia, the second (b) and third (c) conditions above are always the missing features.

\section{References:}

Adamu, A. (2005). True federalism in 21 st century Nigeria. Lecture of Governor of Nasarawa State, Lagos, 24

Artus, P. (2011). True federalism and federalism as seen from Germany. Natixis. Retrieved from http://cib.natixis.com/flushdoc.aspx?id=61340

Bhattacharyya, H. (2002). Making Local Democracy Work in India: Social Capital, Politics \& Governance in West Bengal. eBooks (P): Vedams Ltd.

Bolarinwa, J. O. (2014). Reinventing True Federalism in Nigeria: A Perspective. IUP Journal of International Relations, 8(3), 40-54.

Dardanelli, P. (2010). Federal democracy in Switzerland. In M. Burgess \& A.-G. Gagnon (Eds.), Federal democracies (pp. 142-159). London: Routledge.

Ejobowah, J. B. (2009). Rewriting Nigerian federal constitution: A prescriptive argument for a self-sustaining arrangement. Canadian Journal of African Studies/La Revue canadienne des études africaines, 43(3), 507535.

Elaigwu, J. I. (2002). Federalism in Nigeria's new democratic polity. Publius: The Journal of Federalism, 32(2), 73-96.

Elazar, D. J. (1980). The political theory of covenant: Biblical origins and modern developments. Publius, 10(4), 3-30.

Elazar, D. J. (1987). Exploring federalism. Tuscaloosa, AL: University of Alabama Press

Elazar, D. J. (Ed.). (1969). Cooperation and conflict: Readings in American federalism. Itasca, Ill: FE Peacock Publishers.

Elebeke, E. (2014, June 6). True federalism will address Nigeria's insecurity - Justice Bello. Vanguard.

Franck, T. M. (1968). Why federations fail: An inquiry into the requisites for successful federalism: New York University Press.

Friedrich, C. J. (1968). Trends of federalism in theory and practice. London: Pall Mall Press.

Grodzins, M. (1966). The American system: A new view of government in the United States: Transaction Publishers.

Heidler, D. S., \& Heidler, J. T. (2006). The Mexican War: Greenwood Publishing Group.

Heuvel, W. J. V. (2000). The Future of Freedom in Russia: Templeton Foundation Press.

Hodgins, B., \& Wright, D. (1978). Canada and Australia: Continuing but changing federations. In B. Hodgins, D. Wright \& W. Heick (Eds.), 
Federalism in Canada and Australia: The early years (pp. 289-305). Waterloo, Ont.: Wilfrid Laurier University Press.

IAS Baba. (2015). The spirit of True Federalism in India. Retrieved from http://iasbaba.com/2015/10/3-what-do-you-understand-by-true-federalismdo-you-think-india-need-to-overhaul-its-federal-character-to-match-thespirit-of-true-federalism-comment/

Ikein, A. A., Alamieyeseigha, D. S., \& Azaiki, S. S. (2008). Oil, Democracy, and the Promise of True Federalism in Nigeria: University press of America. Kalu, K. N. (2015, Friday, 27th February). Democracy and its travails: Fallacy of 'true' federalism. Guardian Nigeria. Retrieved from http://www.ngrguardiannews.com/features/focus/199753-democracy-and-itstravails-fallacy-of-true-federalism

Khalid, I. (2013). Politics of Federalism in Pakistan: Problems and Prospects. South Asian Studies, 28(1), 199-212.

Livingston, W. S. (1956). Federalism and constitutional change. London: Oxford University Press.

Mehta, P. S. (2014, April 2). The road to true federalism. Business Standard. Retrieved from http://www.business-standard.com/article/opinion/pradeep-smehta-the-road-to-true-federalism-114040201257_1.html

Merchant, D., \& Rich, P. (2003). Prospects for Mexican federalism: Roots of the policy issues. Policy Studies Journal, 31(4), 661-667.

Moots, G. A. (2009). The covenant tradition of federalism: The pioneering studies of Daniel J. Elazar. The Ashgate Research Companion to Federalism, 391-412.

Naqvi, M. B. (2010). Pakistan at knife's edge: Roli Books Private Limited.

Odje, A. M. (2002). Challenges of true federalism \& resource control in Nigeria: Akpo Mudiaga Odje.

Papillon, M. (2008). Federalism from Below? The emergence of Aboriginal multilevel governance in Canada: A comparison of the James Bay Crees and Kahnawa: ke Mohawks. University of Toronto.

Pelletier, B. (2005). Asymmetrical Federalism: A Win-Win Formula Kingston, Ont.: Queen's University

Petrov, N., \& Slider, D. (2015). Regional politics. In S. K. Wegren (Ed.), Putin's Russia: Past Imperfect, Future Uncertain (pp. 63-82). Lanham, MD: Rowman \& Littlefield.

Ponce de León, E. Z. (1999, October 6). Progress and Challenges of Mexican Federalism. Paper presented at the International Forum of Federations, Mont-Tremblant, Canada. Retrieved from http://zedillo.presidencia.gob.mx/welcome/PAGES/library/sp_07oct99.html Riker, W. H. (1964). Federalism: Origin, operation, significance. Boston, MA: Little Brown. 
Ross, C. (2000). Federalism and democratization in Russia. Communist and Post-Communist Studies, 33(4), 403-420.

Sagay, I. (2014). Resource governance in Nigeria: 1960-2013. In J. A. A. Ayoade (Ed.), Nigeria: Descent into anarchy and collapse? (pp. 194-226). Ibadan: John Archers Ltd.

Salikov, M. (2003). The Russian federal system: sub-national and local levels. Urals Law Academy Yekaterinburg Russia. Retrieved from http://camlaw.rutgers.edu/statecon/subpapers/salikov.pdf

Schlesinger, R. (2013). Federalism in Central and Eastern Europe: Routledge.

Senator Olubiyi Durojaiye. (2014). 'Why Yorubas insist on true federalism'. In Olayinka Ajayi (Ed.). Vanguard.

Suberu, R. (2009). Federalism in Africa: The Nigerian experience in comparative perspective. Ethnopolitics, 8(1), 67-86.

Verny, D. (1998). Issues in federalism Federalism in Russia: How is it working? (National Intelligence Council and the State Department Bureau of Intelligence and Research.

Watts, R. L. (1966). New federations: Experiments in the Commonwealth. Oxford, UK: Clarendon Press.

Watts, R. L. (2008). Comparing federal systems (3rd ed.). Kingston, Ont.: McGill-Queen's University Press.

Wayas, J. (1998). Only True Federalism can Save Nigeria. The Guardian, 41.

Wegierski, M. (2011). In search of true federalism in Canada: Old Canada, New Canada, and "Canada Three". Retrieved from http://www.enterstageright.com/archive/articles/0511/0511truefed.htm

Wheare, K. C. (1963). Federal government (4th ed.). London: Oxford University Press.

Wingo, H. (1986). US and Canadian federalism: A study in contrast. Vermont Law Review, 11(473), 473-503.

Witte, E., Craeybeckx, J., \& Meynen, A. (2009). Political history of Belgium: From 1830 onwards: ASP/VUBPRESS/UPA. 